\title{
Endocannabinoid System: behavioral modulation in murine models by Cannabinoids
}

\section{type 2 receptors}

\author{
Sistema endocanabinóide: modullação comportamental em modelos murinos por receptores de \\ canabinóides tipo 2
}

\section{Sistema endocannabinoide: modulación del comportamiento en modelos murinos por receptores} cannabinoides tipo 2

Rayan Fidel Martins Monteiro ORCID: https://orcid.org/0000-0001-6642-4488 Federal University of Pará, Brazil E-mail: rayanfidel@hotmail.com

Marcos Vinícius Lebrego Nascimento ORCID: https://orcid.org/0000-0002-4758-4459 Federal University of Pará, Brazil

E-mail: lebregonascimento@yahoo.com.br Klinsmann Thiago Lima ORCID: https://orcid.org/0000-0003-3635-0072 Federal University of Pará, Brazil E-mail: klinsmanntl@gmail.com

José Ramon Gama Almeida

ORCID: https://orcid.org/0000-0002-9871-0531 Federal University of Pará, Brazil

E-mail: ramonalmeida1703@gmail.com

Paulo Eduardo Santos Ávila

ORCID: https://orcid.org/0000-0002-4806-3719 Federal University of Pará, Brazil E-mail: pauloavila@yahoo.com

Gilmara de Nazareth Tavares Bastos

ORCID: https://orcid.org/0000-0002-4899-6500 Federal University of Pará, Brazil E-mail: bastosgnt@gmail.com

\begin{abstract}
In the last decades, the eCB system has been highlighted by its neuro and immunomodulatory effects. Beyond $\mathrm{CB}_{1} \mathrm{R}$ effects in Central Nervous System (CNS), $\mathrm{CB}_{2} \mathrm{R}$ target drugs has been showed to be promising to mitigation of neuroinflammatory diseases in mouse models. However, it remains unknow the effects of $\mathrm{CB}_{2} \mathrm{R}$ target drugs on behavior. Therefore, we review the effects of $\mathrm{CB}_{2} \mathrm{R}$ on behavior in murine models by Pubmed website, selecting studies between 2001 to 2021. In this sense, many studies has demonstrated the effects of overexpression, lack, activation or antagonization of $\mathrm{CB}_{2} \mathrm{R}$ on Aggressive behavior, Memory-associated behaviors, Mood disorders and Reward behavior. Similarly, it is not clear yet how the eCB system modulates the behavior through $\mathrm{CB}_{2} \mathrm{Rs}$ present in neurons. Thus, in mouse models, although the pharmacological treatment with $\mathrm{CB}_{2} \mathrm{R}$ target drugs seems to be promising for neuroinflammatory diseases, on behavior there are few answers about the pathways of this modulation, as well as, it is fundamental the development and/or the update of behavioral tests that evaluate many parameters, then expose better interpretations in these tests.
\end{abstract}

Keywords: Cannabinoid receptor type 2; Endocannabinoid system; Behavioral modulation; Mood disorders; $\mathrm{CB}_{2} \mathrm{R}$ target drugs; Behavioral tests.

\section{Resumo}

Nas últimas décadas, o sistema eCB tem se destacado por seus efeitos neuro e imunomoduladores. Além dos efeitos do $\mathrm{RCB}_{1}$ no Sistema Nervoso Central (SNC), os medicamentos alvo do $\mathrm{RCB}_{2}$ têm se mostrado promissores na mitigação de doenças neuroinflamatórias em modelos de camundongos. No entanto, permanecem desconhecidos os efeitos das drogas alvo do $\mathrm{RCB}_{2}$ no comportamento. Portanto, revisamos os efeitos do $\mathrm{RCB}_{2}$ no comportamento em modelos murinos pelo site Pubmed, selecionando estudos entre 2001 a 2021. Nesse sentido, muitos estudos têm demonstrado os efeitos da superexpressão, falta, ativação ou antagonização do $\mathrm{RCB}_{2}$ no Comportamento agressivo, nos Comportamentos associados à memória, nos Transtornos de humor e no Comportamento de recompensa. Da 
mesma forma, ainda não está claro como o sistema eCB modula o comportamento por meio dos $\mathrm{RCB}_{2} \mathrm{~S}$ presentes nos neurônios. Assim, em modelos de camundongos, embora o tratamento farmacológico com fármacos alvo do $\mathrm{RCB}_{2}$ pareça promissor para doenças neuroinflamatórias, sobre o comportamento existem poucas respostas sobre as vias desta modulação, bem como, é fundamental o desenvolvimento e/ou atualização de testes comportamentais que avaliam muitos parâmetros e, por conseguinte, expõem melhores interpretações nesses testes.

Palavras-chave: Receptor canabinóide do tipo 2; Sistema endocanabinóide; Modulação comportamental; Transtornos de Humor; Drogas alvo de $\mathrm{RCB}_{2}$; Testes comportamentais.

\section{Resumen}

En las últimas décadas, el sistema eCB se ha destacado por sus efectos neuro e inmunomoduladores. Más allá de los efectos de $\mathrm{RCB}_{1}$ en el Sistema Nervioso Central (SNC), se ha demostrado que los fármacos diana de $\mathrm{RCB}_{2}$ son prometedores para la mitigación de enfermedades neuroinflamatorias en modelos de ratón. Sin embargo, se desconocen los efectos de los fármacos diana $\mathrm{RCB}_{2}$ sobre el comportamiento. Por ello, revisamos los efectos del $\mathrm{RCB}_{2}$ sobre el comportamiento en modelos murinos por la web Pubmed, seleccionando estudios entre 2001 y 2021. En este sentido, numerosos estudios han demostrado los efectos de la sobreexpresión, falta, activación o antagonización del $\mathrm{RCB}_{2}$ sobre el comportamiento agresivo, Memory- comportamientos asociados, trastornos del estado de ánimo y comportamiento de recompensa. Del mismo modo, aún no está claro cómo el sistema eCB modula el comportamiento a través de los $\mathrm{RCB}_{2}$ presentes en las neuronas. Así, en modelos de ratón, aunque el tratamiento farmacológico con fármacos diana $\mathrm{RCB}_{2}$ parece prometedor para las enfermedades neuroinflamatorias, sobre el comportamiento existen pocas respuestas sobre las vías de esta modulación, así como, es fundamental el desarrollo y/o la actualización de pruebas de comportamiento que evalúan muchos parámetros, luego exponen mejores interpretaciones en estas pruebas.

Palabras clave: Receptor de cannabinoides tipo 2; Sistema endocannabinoide; Modulación del comportamiento; Trastornos del estado de ánimo; Fármacos diana $\mathrm{RCB}_{2}$; Pruebas de comportamiento.

\section{Introduction}

\section{Endocannabinoid System}

The Endocannabinoid (eCB) system raised in the academic world in the end of the last century, since then its modulatory effects on other systems have been highlighted, mainly by its neuro and immunomodulatory effects.

The eCB system is characterized mainly by two cannabinoid receptors: type $1\left(\mathrm{CB}_{1} \mathrm{R}\right)$ and type $2\left(\mathrm{CB}_{2} \mathrm{R}\right)$. Both are $\mathrm{G}$ protein-coupled, which $\mathrm{CB}_{1} \mathrm{R}$ was mainly linked to neural modulation, whereas $\mathrm{CB}_{2} \mathrm{R}$ was mainly linked to immune modulation (Castillo, Younts, Chavez, \& Hashimotodani, 2012; Piomelli, 2003). However, more recently it is clear a double receptor modulation in immune and nervous system by both $\mathrm{CB}_{1}$ and $\mathrm{CB}_{2}$ receptors (Borner, Smida, Hollt, Schraven, \& Kraus, 2009; McCoy, 2016; Naguib et al., 2012; Stella, 2010). Here, our review focuses mainly $\mathrm{CB}_{2} \mathrm{R}$ effects on behavioral modulation in mouse models.

In this sense, the immunomodulatory effect of activation of $\mathrm{CB}_{2} \mathrm{R}$ by the activation of Protein Kinase $\mathrm{A}$ in immunological, epithelial (Basu \& Dittel, 2011; Borner et al., 2009; Persidsky et al., 2015), and glial cells (Ehrhart et al., 2005; Merighi, Gessi, Varani, Fazzi, et al., 2012; Merighi, Gessi, Varani, Simioni, et al., 2012) has been promising to many inflammatory diseases, such as obesity (Q. Wu et al., 2020), Parkinson disease (Concannon, Okine, Finn, \& Dowd, 2015; Price et al., 2009), Sepse (Tschop et al., 2009), Stroke (Ronca et al., 2015), and Alzheimer disease (J. Wu et al., 2013). In addition, the activation of $\mathrm{CB}_{2} \mathrm{R}$ as a pharmacological target to neuroinflammatory diseases is an alternative against the psychotropic effects of the activation of $\mathrm{CB}_{1} \mathrm{R}$ within the attributions of eCB system: the side effects of marihuana (Cannabis) use are mainly due to $\mathrm{CB}_{1} \mathrm{R}$ activation by $\mathrm{THC}$ ( $\Delta$ 9-tetrahydrocannabinol) (Hashiesh et al., 2020; Volkow, Baler, Compton, \& Weiss, 2014).

In contrast, the presence of $\mathrm{CB}_{2} \mathrm{R}$ in neurons has motivated the research for neuromodulators effects of the systemic activation of $\mathrm{CB}_{2} \mathrm{R}$ to know the possibility of side effects, as well as to know the possibility of treatment of mood disorders, such as anxiety and depression (Chen, Gao, Gao, Su, \& Wu, 2017). Therefore, the neuromodulators effects of eCB System by $\mathrm{CB}_{2} \mathrm{R}$ remain unknow, mainly in behavior. Thus, our goal was review and systematize the $\mathrm{CB}_{2} \mathrm{R}$ effects on behavioral 
modulation in murine models.

\section{Methodology}

The source of this review comprehends studies from PubMed website, which the keyworks was: "Cannabinoid receptor type 2"; "Endocannabinoid system"; and "Behavioral test". Thus, the first step was the select of studies between 2001 to 2021. Our goal was select experimental studies that have used behavioral tests in mouse models with overexpression, lack, activation or antagonization of $\mathrm{CB}_{2} \mathrm{R}$, which includes $\mathrm{CB}_{2} \mathrm{R}$ target drugs (agonists and/or antagonists), $\mathrm{CB}_{2} \mathrm{R}-\mathrm{knockout}$ mice, overexpression or lack of $\mathrm{CB}_{2} \mathrm{R}$ by other methodologies. The second step was select the main literature studied in behavioral clusters. The last step was including additional studies to explain our view point about our conclusions overall. According to Estrela, (2018) our study can be considerable a Narrative Revision (Estrela, 2018).

\section{Results and Discussion}

During our search, we systematize 12 methodologies, 33 effects/outcomes from 10 studies in 4 behavioral clusters: Aggressive behavior, Memory-associated behavior, Mood disorders and Reward behavior. Furthermore, some effects/outcomes appear more than once and can be linked to more than one of the 4 behavioral clusters (Table 1).

\section{Aggressive behavior}

Aggressiveness could be found in any mammal, likewise it stands as an important preserved behavior since mouse to humans. In this sense, Rodriguez-Arias, et al (2013) demonstrated that $\mathrm{CB}_{1} \mathrm{R}$ could be present in aggressive modulation in mice model (Rodriguez-Arias et al., 2013). Similarly, later the same group also showed that $\mathrm{CB}_{2} \mathrm{R}$-knockout mice are more aggressive than wild type (WT), whereas acute administration of $\mathrm{CB}_{2} \mathrm{R}$-agonist attenuate the aggressiveness in WT after isolation, while the $\mathrm{CB}_{2} \mathrm{R}$-antagonist reversed it, in addition the $\mathrm{CB}_{2} \mathrm{R}$-knockout mice did not have its aggressiveness changed by isolation, indicating a modulatory effect on aggressive behavior by $\mathrm{CB}_{2} \mathrm{R}$ (Rodriguez-Arias et al., 2015). Thus, supporting the eCB system as an aggressive behavior modulator by both $\mathrm{CB}_{1}$ and $\mathrm{CB}_{2}$ receptors.

\section{Memory-associated behavior}

Memory could determinates our decisions and consequently our behavior. Therefore, murine models have been used to quantify it by behavioral tests. In this sense, Garcia-Gutierrez, et al (2013) reported an impairment in the short and long term contextual memory in $\mathrm{CB}_{2} \mathrm{R}$-knockout mice and in $\mathrm{CB}_{2} \mathrm{R}$-antagonist acute treatment, while the $\mathrm{CB}_{2} \mathrm{R}$-agonist acute treatment improved it in Step-down inhibitory avoidance test (SDIA), however it was not clear if these differences are in contextual memory itself or in the exploratory behavior: $\mathrm{CB}_{2} \mathrm{R}$-knockout mice, for example, expressed difference against WT in the train part of SDIA in this study, suggesting then an exploratory behavior modulation which may have confounded the results (Garcia-Gutierrez et al., 2013).

Similarly, Lim and Kim (2016a) had controversial results to linked the lack of $\mathrm{CB}_{2} \mathrm{R}$ to contextual memory either, $\mathrm{CB}_{2} \mathrm{R}$-knockout mice showed a contextual memory impairment by decreased of freezing in contextual test without difference in cued test of Fear conditioning behavior test (FCBT), as well as the $\mathrm{CB}_{2} \mathrm{R}$ antagonist acute administration did not promote any difference in FCBT or Y-maze test (YMT), furthermore $\mathrm{CB}_{2} \mathrm{R}$-knockout mice showed increased in spontaneous alteration in YMT (Li \& Kim, 2016a). Later, the same group brought out an elegant study, they reported that the overexpression of $\mathrm{CB}_{2} \mathrm{R}$ in pyramidal cells or interneurons from CA1 area of hippocampus did not promote any change in YMT, FCBT or Novel object test (NOT), whereas the lack of $\mathrm{CB}_{2} \mathrm{R}$ in pyramidal cells from the same area by CRISPR (Clustered regularly interspaced short 
palindromic repeats) promotes increased in spontaneous alteration in YMT, as well as, by the same methodologies, the overexpression of $\mathrm{CB}_{2} \mathrm{R}$ in microglial cells from $\mathrm{CA} 1$ area of hippocampus promotes increased of freezing in contextual text of FCBT, whereas the lack of $\mathrm{CB}_{2} \mathrm{R}$ promotes a decreased of freezing in the same test, however this lack also promotes an improvement in NOT ( $\mathrm{Li} \& \mathrm{Kim}, 2017$ ). Indicating then, an improving of spatial work memory by the lack of $\mathrm{CB}_{2} \mathrm{R}$, however it is not clear yet a $\mathrm{CB}_{2} \mathrm{R}$ modulation on fear memory or spatial memory, as well as it also not clear if that modulation is mediated by neurons or microglial cells.

In addition, in mice models of neural diseases, the $\mathrm{CB}_{2} \mathrm{R}$-agonist chronic treatment has not showed any difference in spatial memory in Morris water maze test (MWM) in Alzheimer's disease model (J. Wu et al., 2013), and has showed a memory-associated recognition impairment in NOT in a stroke model (Ronca et al., 2015). Thus, despite the $\mathrm{CB}_{2} \mathrm{R}$-agonist treatment attenuate damages in these and others neural diseases in mice models, it has not showed good outcomes in memoryassociated behavior. In the other hand, the eCB system stands present in memory-associated behavior, especially in fearassociated behavior and this modulation is more associated with the $\mathrm{CB}_{2} \mathrm{Rs}$ present in microglial cells, thus it must to be considerate in adoption of treatments with $\mathrm{CB}_{2} \mathrm{R}$ target drugs.

\section{Mood disorders}

Beyond the neuroinflammatory diseases, the eCB system has been also investigated over the mood disorders, which the murine models are large used in these models. Thereby, García-Gutiérrez, et al (2012) has showed that synthetic $\mathrm{CB}_{2} \mathrm{R}-$ antagonist acute-treatment has an anxiogenic effect, whereas the synthetic $\mathrm{CB}_{2} \mathrm{R}$-agonist acute-treatment has no effect in Light-Dark box (LDB), but reversed the effect of $\mathrm{CB}_{2} \mathrm{R}$-antagonist acute-treatment, interestingly the chronic treatments has reversed these effects: the agonist induced an anxiogenic effect and the antagonist induced an anxiolytic effect, which these last effects linked to an expression changes of GABAergic receptors on the cortex and on the Amidala (Garcia-Gutierrez, Garcia-Bueno, Zoppi, Leza, \& Manzanares, 2012). Similarly, the increased time in central area of Open field test (OFT) or open arm of Elevated plus-maze (EPM) promoted after $\beta$-Caryophyllene (BCP) acute-treatment, a $\mathrm{CB}_{2} \mathrm{R}$-agonist, was reported as an anxiolytic effect dependent of $\mathrm{CB}_{2} \mathrm{Rs}$ in these tests (Bahi et al., 2014). Indeed, this increased or decreased in the center of OFT, or in the open arm of EPM, or in the light area of LDB, has reported as an anxiolytic or anxiogenic effect respectively.

In the other hand, $\mathrm{Li} \& \mathrm{Kim}$ (2016a) has showed that $\mathrm{CB}_{2} \mathrm{R}$-knokout mice and $\mathrm{CB}_{2} \mathrm{R}$-agonist acute-treatment does not have effect in the exploratory behavior into aversive areas of typical tests of anxiety-like behavior (Li \& Kim, 2016a). However, the use of knockout mice to research for eCB system roles is questionable because eCB system is present in Central nervous system (CNS) development (Harkany et al., 2007). In addition, it is unclear whether the typical tests of anxiety-like behavior in mouse models, such as OFT, EPM, LDB and Zero-maze test (ZMT) evaluate precisely this behavior (Ennaceur \& Chazot, 2016). Moreover, recently it has showed that the overexpression of $\mathrm{CB}_{2} \mathrm{Rs}$ in glutamatergic neurons from $\mathrm{CA} 1$ area of hippocampus also induced increased of activity in the central area of OFT, without alteration in ZMT (Li \& Kim, 2017). It suggests that the increased of exploratory activity in aversive area of OFT could be does not associated with anxiety-like behavior. Thus, it must to be more investigated.

Furthermore, over the depression-like behavior, Bahi, et al (2014) also demonstrated that BCP acute-treatment decreased the latency to eat in Novelty suppressed feeding test (NSFT), and decreased the immobility time in Forced swim test (FST) and in Tail suspension test (TST) in mice model, whereas the action of acute-treatment with $\mathrm{CB}_{2}$ R-antagonist reversed these results (Bahi et al., 2014). It supports the use of $\mathrm{CB}_{2} \mathrm{R}$ as a pharmacological target to mood disorders, however there are few data to corroborate it yet. Nonetheless, the BCP treatment has other targets beyond $\mathrm{CB}_{2} \mathrm{R}$ (Gertsch et al., 2008; Hashiesh et al., 2020), which means it is necessary an investigation for its outcomes in mice models of depression-like behavior. 
Table 1. The effects/outcomes of $\mathrm{CB}_{2} \mathrm{R}$ on behavioral tests in mouse models.

\begin{tabular}{|c|c|c|}
\hline \multicolumn{3}{|l|}{ Aggressive behavior } \\
\hline Methodology & Effects/Outcomes & Reference \\
\hline Systemic $\mathrm{CB}_{2} \mathrm{R}$-agonist acute-treatment & Decreased of the aggressiveness after isolation & \multirow{4}{*}{ Rodriguez-Arias et al., 2015} \\
\hline Systemic $\mathbf{C B}_{2} \mathbf{R}$-antagonist acute-treatment & Reversed the effect of agonist & \\
\hline \multirow[b]{2}{*}{$\mathrm{CB}_{2}$ R-knockout mice } & Increased of aggressiveness & \\
\hline & $\begin{array}{l}\text { It did not promote any difference in aggressiveness } \\
\text { after isolation }\end{array}$ & \\
\hline \multicolumn{3}{|l|}{ Memory-associated behavior } \\
\hline Methodology & Effects/Outcomes & Reference \\
\hline Systemic $\mathrm{CB}_{2} \mathrm{R}$-agonist acute-treatment & $\begin{array}{l}\text { Improvement in the short and long term contextual } \\
\text { memory }\end{array}$ & \multirow{3}{*}{ Garcia-Gutierrez et al., 2013} \\
\hline Systemic $\mathrm{CB}_{2} \mathrm{R}$-antagonist acute-treatment & \multirow{2}{*}{$\begin{array}{c}\text { Impairment in the short and long term contextual } \\
\text { memory }\end{array}$} & \\
\hline $\mathrm{CB}_{2} \mathrm{R}-$-knockout mice & & \\
\hline Systemic $\mathrm{CB}_{2} \mathrm{R}$-antagonist acute-treatment & It did not promote any difference in FCBT or YMT & \multirow{3}{*}{ Li \& Kim, 2016a } \\
\hline \multirow[t]{2}{*}{$\mathrm{CB}_{2} \mathrm{R}$-knockout mice } & $\begin{array}{l}\text { Impairment in contextual memory by decreased of } \\
\text { freezing in contextual test without difference in cued } \\
\text { test of FCBT }\end{array}$ & \\
\hline & Increased in spontaneous alteration in YMT & \\
\hline $\begin{array}{l}\text { Overexpression of } \mathrm{CB}_{2} \mathrm{R} \text { in pyramidal cells } \\
\text { from } \mathrm{CA} 1 \text { area of hippocampus }\end{array}$ & It did not promote any change in YMT, FCBT or & \multirow{6}{*}{ Li \& Kim, 2017} \\
\hline $\begin{array}{l}\text { Overexpression of } \mathrm{CB}_{2} \mathrm{R} \text { in interneurons } \\
\text { from CA1 area of hippocampus }\end{array}$ & NOT & \\
\hline $\begin{array}{c}\text { Lack of } \mathrm{CB}_{2} \mathrm{R} \text { in pyramidal cells from CA1 } \\
\text { area of hippocampus by CRISPR }\end{array}$ & Increased in spontaneous alteration in YMT & \\
\hline $\begin{array}{l}\text { Overexpression of } C_{3} B_{2} R \text { in microglial cells } \\
\text { from CA1 area of hippocampus }\end{array}$ & Increased of freezing in contextual text of FCBT & \\
\hline \multirow{2}{*}{$\begin{array}{l}\text { Lack of } \mathrm{CB}_{2} \mathrm{R} \text { in the in microglial cells from } \\
\text { CA1 area of hippocampus by CRISPR }\end{array}$} & Decreased of freezing in contextual text of FCBT & \\
\hline & $\begin{array}{c}\text { Improvement in memory-associated recognition in } \\
\text { NOT }\end{array}$ & \\
\hline \multirow[b]{2}{*}{ Systemic $\mathrm{CB}_{2} \mathrm{R}$-agonist chronic-treatment } & It did not promote effects in MWM & J. Wu et al., 2013 \\
\hline & $\begin{array}{c}\text { Impairment in memory-associated recognition in } \\
\text { NOT }\end{array}$ & Ronca et al., 2015 \\
\hline \multicolumn{3}{|l|}{ Mood disorders } \\
\hline Methodology & Effects/Outcomes & Reference \\
\hline Systemic $\mathrm{CB}_{2} \mathrm{R}$-antagonist acute-treatment & Decreased the time in light box of LDB & \multirow{4}{*}{$\begin{array}{l}\text { Garcia-Gutierrez, Garcia-Bueno, } \\
\text { Zoppi, Leza, \& Manzanares, } 2012\end{array}$} \\
\hline Systemic $C_{B} R$-agonist acute-treatment & Reversed the effect of antagonist & \\
\hline $\mathrm{CB}_{2} \mathrm{R}$-antagonist chronic-treatment & Increased the time in aversive areas of LDB and EPM & \\
\hline Systemic $\mathbf{C B}_{2} \mathbf{R}$-agonist chronic-treatment & $\begin{array}{l}\text { Decreased the time in aversive areas of LDB and } \\
\text { EPM }\end{array}$ & \\
\hline $\mathrm{CB}_{2}$ R-knockout mice & \multirow{2}{*}{ It did not promote any effect in OFT or ZMT } & \multirow{3}{*}{ Li \& Kim, 2016a } \\
\hline Systemic $C_{2} R$-agonist acute-treatment & & \\
\hline Systemic $C_{2}$ R-antagonist acute-treatment & Reversed the effects of agonist & \\
\hline \multirow{2}{*}{$\begin{array}{l}\text { Overexpression of } \mathrm{CB}_{2} \mathrm{R} \text { in glutamatergic } \\
\text { neurons from } \mathrm{CA} 1 \text { area of hippocampus }\end{array}$} & Increased of activity in the central area of OFT & \multirow{2}{*}{ Li \& Kim, 2017} \\
\hline & It did not promote any effect in ZMT & \\
\hline \multirow{3}{*}{ Systemic $\mathrm{CB}_{2} \mathrm{R}$-agonist acute-treatment } & Increased the time in aversive areas of OFT and EPM & \multirow{3}{*}{ Bahi et al., 2014} \\
\hline & Decreased the latency to eat in NSFT & \\
\hline & Decreased the immobility time in FST and in TST & \\
\hline \multicolumn{3}{|l|}{ Reward behavior } \\
\hline Methodology & Effects/Outcomes & Reference \\
\hline \multirow{2}{*}{$\begin{array}{l}\text { Systemic, intranasal or intra-accumbens } \\
\mathrm{CB}_{2} \mathrm{R} \text {-agonist acute-treatment }\end{array}$} & Inhibits the cocaine self-administration & \multirow{2}{*}{ Xi et al., 2011} \\
\hline & Inhibits the hyper activity induced by cocaine & \\
\hline Systemic $\mathrm{CB}_{2} \mathrm{R}$-agonist acute-treatment & \multirow[b]{2}{*}{ Increased of activity in the central area of OFT } & Bahi et al., 2014 \\
\hline $\begin{array}{l}\text { Overexpression of } \mathrm{CB}_{2} \mathrm{R} \text { in glutamatergic } \\
\text { neurons from CA1 area of hippocampus }\end{array}$ & & Li \& Kim, 2017 \\
\hline Systemic $\mathrm{CB}_{2} \mathrm{R}$-agonist acute-treatment & Inhibits the hyper activity induced by cocaine & \multirow{2}{*}{$\begin{array}{c}\text { Lopes, Bastos, Costa, Aguiar, \& } \\
\text { Moreira, } 2020\end{array}$} \\
\hline Systemic $\mathbf{C B}_{2} \mathrm{R}$-agonist chronic-treatment & Reversed the effect of agonist & \\
\hline
\end{tabular}

Source: Authors (2021).

\section{Reward behavior}

The eCB system has been showed in mesolimbic pathway, thus in the modulation of reward behavior, which is a fundamental target in the mitigation of side effects from psychoactive drugs. In this sense, the chronic activation of $\mathrm{CB}_{2} \mathrm{Rs}$ in 
the hippocampus increased synaptic transmission ( $\mathrm{Kim} \& \mathrm{Li}$, 2015). Completely, $\mathrm{CB}_{2} \mathrm{R}$-kockout mice has decreased of excitatory synapse in the hippocampus ( $\mathrm{Li} \& \mathrm{Kim}, 2016 \mathrm{~b}$ ). As well as, the strength of hippocampus nucleus-accumbens (NAc) synapse drives conditioned place preference, similarly as the use of anti-depressive drugs is linked to the increased of this pathway, and differently as the chronic stress is linked to the decreased of this pathway (LeGates et al., 2018). The NAc has an important role in mesolimbic pathway about the regulation of dopamine levels, motor activity and NAc is also linked to behavior changes induced by drugs abuse intake, however NAc roles remains unknown, but the hippocampus-NAc input has showed important modulatory effect in reward behavior (Perez \& Lodge, 2018; Scudder, Baimel, Macdonald, \& Carter, 2018).

Therefore, we suggest that the increased in central area of OFT by $\mathrm{CB}_{2} \mathrm{R}$-acute treatment (Bahi et al., 2014) or overexpression of $\mathrm{CB}_{2} \mathrm{Rs}$ in glutamatergic neurons from $\mathrm{CA} 1$ area of hippocampus ( $\mathrm{Li} \& \mathrm{Kim}, 2017$ ) would be linked to a eCB system neuro-modulatory effect in reward behavior by an increase of exploration, instead of anxiety-like behavior.

In addition, the eCB system has also linked to mesolimbic pathway by presence of $\mathrm{CB}_{2} \mathrm{Rs}$ in dopaminergic neurons of ventral tegmental area (Zhang et al., 2014). Completely, the systemic, the intranasal or the intra-accumbens acute treatment with $\mathrm{CB}_{2} \mathrm{R}$-agonist inhibits the cocaine self-administration and inhibits the increased of hyper activity induced by cocaine, whereas this drug effect is absent in $\mathrm{CB}_{2} \mathrm{R}$-knockout mice (Xi et al., 2011). Similarly, Lopes, et al (2019) also demonstrated that acute administration of $\mathrm{CB}_{2} \mathrm{R}$-agonist inhibits hyper activity induced by cocaine, whereas the $\mathrm{CB}_{2} \mathrm{R}$-antagonist reversed it (Lopes, Bastos, Costa, Aguiar, \& Moreira, 2020). It supports an interesting application in mitigation of side effects of abuse drugs by pharmacological treatment of $\mathrm{CB}_{2} \mathrm{R}$ target drugs.

\section{Conclusion}

In summary, after few years of eCB system discovered, there are a range of studies and reviews about its modulatory effect on CNS, and it is clear a large potential of the use of eCB system as a pharmacological target for many diseases, especially in immune and neural diseases, however, it remains unknow these effects on behavior. In this review we systematize 12 methodologies, 33 effects/outcomes from 10 studies in 4 behavioral clusters (Table 1). Thus, we conclude the eCB system modulates behaviors by $\mathrm{CB}_{2} \mathrm{R}$ in mouse models, which includes Aggressive behavior, Memory-associated behavior, Mood disorders and Reward behavior, as well as, the $\mathrm{CB}_{2} \mathrm{R}$ target drugs has a large potential to be a pharmacological treatment in Mood disorders and mitigation of side effects promoted by abuse drugs. However, in spite of a considerable number of studies that linked the presence, the lack, the activation or the antagonization of $\mathrm{CB}_{2} \mathrm{R}$ to behavioral changes, there are a few answers about which other behaviors could be modulated by it, as well as, there is not sure about all consequences of acute or chronic treatment with agonists or antagonists of $\mathrm{CB}_{2} \mathrm{R}$. This lack of answers is promoted both by the complexity of eCB system and the controversial interpretations in behavioral tests. In this sense, it is necessary future researches to multi target treatments into eCB system, including receptor side effects and physiology and pharmacology behavioral effects modulated by $\mathrm{CB}_{2} \mathrm{R}$. As well as, the development and/or the update of behavioral tests that can evaluate the correlation of behavioral parameters and eCB system should be provide.

\section{Acknowledgments}

This study was supported by grants from the National Council of Scientific and Technological Development (CNPq), CAPES and Fundação Amazônia Paraense de Amparo à Pesquisa (FAPESPa), PROPESP/UFPA.

\section{References}

Bahi, A., Al Mansouri, S., Al Memari, E., Al Ameri, M., Nurulain, S. M., \& Ojha, S. (2014). beta-Caryophyllene, a CB2 receptor agonist produces multiple behavioral changes relevant to anxiety and depression in mice. Physiol Behav, 135, 119-124. 10.1016/j.physbeh.2014.06.003 
Basu, S., \& Dittel, B. N. (2011). Unraveling the complexities of cannabinoid receptor 2 (CB2) immune regulation in health and disease. Immunol Res, 51(1), 26-38. $10.1007 / \mathrm{s} 12026-011-8210-5$

Borner, C., Smida, M., Hollt, V., Schraven, B., \& Kraus, J. (2009). Cannabinoid receptor type 1- and 2-mediated increase in cyclic AMP inhibits T cell receptor-triggered signaling. J Biol Chem, 284(51), 35450-35460. 10.1074/jbc.M109.006338

Castillo, P. E., Younts, T. J., Chavez, A. E., \& Hashimotodani, Y. (2012). Endocannabinoid signaling and synaptic function. Neuron, 76(1), 70-81. 10.1016/j.neuron.2012.09.020

Chen, D. J., Gao, M., Gao, F. F., Su, Q. X., \& Wu, J. (2017). Brain cannabinoid receptor 2: expression, function and modulation. Acta Pharmacol Sin, 38(3), 312-316. 10.1038/aps.2016.149

Concannon, R. M., Okine, B. N., Finn, D. P., \& Dowd, E. (2015). Differential upregulation of the cannabinoid CB(2) receptor in neurotoxic and inflammationdriven rat models of Parkinson's disease. Exp Neurol, 269, 133-141. 10.1016/j.expneurol.2015.04.007

Ehrhart, J., Obregon, D., Mori, T., Hou, H., Sun, N., Bai, Y., \& Shytle, R. D. (2005). Stimulation of cannabinoid receptor 2 (CB2) suppresses microglial activation. J Neuroinflammation, 2, 29. 10.1186/1742-2094-2-29

Ennaceur, A., \& Chazot, P. L. (2016). Preclinical animal anxiety research - flaws and prejudices. Pharmacol Res Perspect, 4(2), e00223. 10.1002/prp2.223 Garcia-Gutierrez, M. S., Garcia-Bueno, B., Zoppi, S., Leza, J. C., \& Manzanares, J. (2012). Chronic blockade of cannabinoid CB2 receptors induces anxiolytic-like actions associated with alterations in GABA(A) receptors. Br J Pharmacol, 165(4), 951-964. 10.1111/j.1476-5381.2011.01625.x

Estrela, C. (2018). Metodologia científica: ciência, ensino, pesquisa. Artes Médicas.

Garcia-Gutierrez, M. S., Ortega-Alvaro, A., Busquets-Garcia, A., Perez-Ortiz, J. M., Caltana, L., Ricatti, M. J., \& Manzanares, J. (2013). Synaptic plasticity alterations associated with memory impairment induced by deletion of CB2 cannabinoid receptors. Neuropharmacology, 73, 388-396. 10.1016/j.neuropharm.2013.05.034

Gertsch, J., Leonti, M., Raduner, S., Racz, I., Chen, J. Z., Xie, X. Q., \& Zimmer, A. (2008). Beta-caryophyllene is a dietary cannabinoid. Proc Natl Acad Sci U $S$ A, 105(26), 9099-9104. 10.1073/pnas.0803601105

Harkany, T., Guzman, M., Galve-Roperh, I., Berghuis, P., Devi, L. A., \& Mackie, K. (2007). The emerging functions of endocannabinoid signaling during CNS development. Trends Pharmacol Sci, 28(2), 83-92. 10.1016/j.tips.2006.12.004

Hashiesh, H. M., Meeran, M. F. N., Sharma, C., Sadek, B., Kaabi, J. A., \& Ojha, S. K. (2020). Therapeutic Potential of beta-Caryophyllene: A Dietary Cannabinoid in Diabetes and Associated Complications. Nutrients, 12(10). 10.3390/nu12102963

Kim, J., \& Li, Y. (2015). Chronic activation of CB2 cannabinoid receptors in the hippocampus increases excitatory synaptic transmission. J Physiol, 593(4), 871-886. 10.1113/jphysiol.2014.286633

LeGates, T. A., Kvarta, M. D., Tooley, J. R., Francis, T. C., Lobo, M. K., Creed, M. C., \& Thompson, S. M. (2018). Reward beh aviour is regulated by the strength of hippocampus-nucleus accumbens synapses. Nature, 564(7735), 258-262. 10.1038/s41586-018-0740-8

Li, Y., \& Kim, J. (2016a). CB2 Cannabinoid Receptor Knockout in Mice Impairs Contextual Long-Term Memory and Enhances Spatial Working Memory. Neural Plast, 2016, 9817089. 10.1155/2016/9817089

Li, Y., \& Kim, J. (2016b). Deletion of CB2 cannabinoid receptors reduces synaptic transmission and long-term potentiation in the mouse hippocampus. Hippocampus, 26(3), 275-281. 10.1002/hipo.22558

Li, Y., \& Kim, J. (2017). Distinct roles of neuronal and microglial CB2 cannabinoid receptors in the mouse hippocampus. Neuroscience, $363,11-25$. 10.1016/j.neuroscience.2017.08.053

Lopes, J. B., Bastos, J. R., Costa, R. B., Aguiar, D. C., \& Moreira, F. A. (2020). The roles of cannabinoid CB1 and CB2 receptors in cocaine-induced behavioral sensitization and conditioned place preference in mice. Psychopharmacology (Berl), 237(2), 385-394. 10.1007/s00213-019-05370-5

McCoy, K. L. (2016). Interaction between Cannabinoid System and Toll-Like Receptors Controls Inflammation. Mediators Inflamm, $2016,5831315$. $10.1155 / 2016 / 5831315$

Merighi, S., Gessi, S., Varani, K., Fazzi, D., Mirandola, P., \& Borea, P. A. (2012). Cannabinoid CB(2) receptor attenuates morphine-induced inflammatory responses in activated microglial cells. Br J Pharmacol, 166(8), 2371-2385. 10.1111/j.1476-5381.2012.01948.x

Merighi, S., Gessi, S., Varani, K., Simioni, C., Fazzi, D., Mirandola, P., \& Borea, P. A. (2012). Cannabinoid CB(2) receptors modulate ERK-1/2 kinase signalling and NO release in microglial cells stimulated with bacterial lipopolysaccharide. Br J Pharmacol, 165(6), 1773-1788. 10.1111/j.14765381.2011.01673.x

Naguib, M., Xu, J. J., Diaz, P., Brown, D. L., Cogdell, D., Bie, B., \& Hittelman, W. N. (2012). Prevention of paclitaxel-induced neuropathy through activation of the central cannabinoid type 2 receptor system. Anesth Analg, 114(5), 1104-1120. 10.1213/ANE.0b013e31824b0191

Perez, S. M., \& Lodge, D. J. (2018). Convergent Inputs from the Hippocampus and Thalamus to the Nucleus Accumbens Regulate Dopamine Neuron Activity. J Neurosci, 38(50), 10607-10618. 10.1523/JNEUROSCI.2629-16.2018

Persidsky, Y., Fan, S., Dykstra, H., Reichenbach, N. L., Rom, S., \& Ramirez, S. H. (2015). Activation of Cannabinoid Type Two Receptors (CB2) Diminish Inflammatory Responses in Macrophages and Brain Endothelium. J Neuroimmune Pharmacol, 10(2), 302-308. 10.1007/s11481-015-9591-3

Piomelli, D. (2003). The molecular logic of endocannabinoid signalling. Nat Rev Neurosci, 4(11), 873-884. 10.1038/nrn1247 
Research, Society and Development, v. 10, n. 13, e356101321491, 2021

(CC BY 4.0) | ISSN 2525-3409 | DOI: http://dx.doi.org/10.33448/rsd-v10i13.21491

Price, D. A., Martinez, A. A., Seillier, A., Koek, W., Acosta, Y., Fernandez, E., \& Giuffrida, A. (2009). WIN55,212-2, a cannabinoid receptor agonist, protects against nigrostriatal cell loss in the 1-methyl-4-phenyl-1,2,3,6-tetrahydropyridine mouse model of Parkinson's disease. Eur J Neurosci, 29(11), $2177-2186$. $10.1111 / \mathrm{j} .1460-9568.2009 .06764 . x$

Rodriguez-Arias, M., Navarrete, F., Blanco-Gandia, M. C., Arenas, M. C., Aguilar, M. A., Bartoll-Andres, A., \& Manzanares, J. (2015). Role of CB2 receptors in social and aggressive behavior in male mice. Psychopharmacology (Berl), 232(16), 3019-3031. 10.1007/s00213-015-3939-5

Rodriguez-Arias, M., Navarrete, F., Daza-Losada, M., Navarro, D., Aguilar, M. A., Berbel, P., \& Manzanares, J. (2013). CB1 cannabinoid receptor-mediated aggressive behavior. Neuropharmacology, 75, 172-180. 10.1016/j.neuropharm.2013.07.013

Ronca, R. D., Myers, A. M., Ganea, D., Tuma, R. F., Walker, E. A., \& Ward, S. J. (2015). A selective cannabinoid CB2 agonist attenuates damage and improves memory retention following stroke in mice. Life Sci, 138, 72-77. 10.1016/j.lfs.2015.05.005

Scudder, S. L., Baimel, C., Macdonald, E. E., \& Carter, A. G. (2018). Hippocampal-Evoked Feedforward Inhibition in the Nucleus Accumbens. J Neurosci, 38(42), 9091-9104. 10.1523/JNEUROSCI.1971-18.2018

Stella, N. (2010). Cannabinoid and cannabinoid-like receptors in microglia, astrocytes, and astrocytomas. Glia, 58(9), 1017-1030. 10.1002/glia.20983

Tschop, J., Kasten, K. R., Nogueiras, R., Goetzman, H. S., Cave, C. M., England, L. G., \& Caldwell, C. C. (2009). The cannabinoid receptor 2 is critical for the host response to sepsis. J Immunol, 183(1), 499-505. 10.4049/jimmunol.0900203

Volkow, N. D., Baler, R. D., Compton, W. M., \& Weiss, S. R. (2014). Adverse health effects of marijuana use. N Engl J Med, 370(23), 2219-2227. 10.1056/NEJMra1402309

Wu, J., Bie, B., Yang, H., Xu, J. J., Brown, D. L., \& Naguib, M. (2013). Activation of the CB2 receptor system reverses amyloid-induced memory deficiency. Neurobiol Aging, 34(3), 791-804. 10.1016/j.neurobiolaging.2012.06.011

Wu, Q., Ma, Y., Liu, Y., Wang, N., Zhao, X., \& Wen, D. (2020). CB2R agonist JWH-133 attenuates chronic inflammation by restraining M1 macrophage polarization via Nrf2/HO-1 pathway in diet-induced obese mice. Life Sci, 260, 118424. 10.1016/j.lfs.2020.118424

Xi, Z. X., Peng, X. Q., Li, X., Song, R., Zhang, H. Y., Liu, Q. R., \& Gardner, E. L. (2011). Brain cannabinoid CB(2) receptors modulate cocaine's actions in mice. Nat Neurosci, 14(9), 1160-1166. 10.1038/nn.2874

Zhang, H. Y., Gao, M., Liu, Q. R., Bi, G. H., Li, X., Yang, H. J., \& Xi, Z. X. (2014). Cannabinoid CB2 receptors modulate midbrain dopamine neuronal activity and dopamine-related behavior in mice. Proc Natl Acad Sci U S A, 111(46), E5007-5015. 10.1073/pnas.1413210111 